\title{
PERANAN LINGKUNGAN TERHADAP KEJADIAN MALARIA DI KECAMATAN SILIAN RAYA KABUPATEN MINAHASA TENGGARA
}

\author{
${ }^{1}$ Melisa Pantow \\ ${ }^{2}$ Josef S. B. Tuda \\ ${ }^{2}$ Angle Sorisi
}

\author{
${ }^{1}$ Kandidat Skripsi Fakultas Kedokteran Universitas Sam Ratulangi Manado \\ ${ }^{2}$ Bagian Parasitologi Fakultas Kedokteran Universitas Sam Ratulangi Manado \\ E-mail: mpantow11_020@yahoo.com
}

\begin{abstract}
Malaria, an infectious disease, is still an issue for public health world-wide, including in Indonesia. Malaria is caused by Plasmodium Sp. which is transmitted by the Anopheles mosquito. Southeast Minahasa Regency has high malaria rate. This study aimed to know the role of the environment on the incidence of malaria in Silian Raya subdistrict, Southeast Minahasa regency. This was a descriptive survey. The population was the community in Silian Raya subdistrict, Southeast Minahasa regency with 194 respondents. The results showed that people in Silian Raya subdistrict mostly live around swamps, rice paddies, and rivers. This study also showed that only a few people of Silian Raya subdistrict who had pets, and fish ponds around their houses.
\end{abstract}

Keywords: malaria, environment

\begin{abstract}
Abstrak: Malaria adalah penyakit menular yang masih menjadi masalah kesehatan masyarakat di Dunia termasuk di Indonesia. Malaria merupakan penyakit yang disebabkan oleh Plasmodium Sp ditularkan oleh nyamuk Anopheles. Kabupaten Minahasa Tenggara merupakan salah satu Kabupaten yang angka malarianya tinggi. Tujuan penelitian ini adalah mengetahui peranan lingkungan terhadap kejadian malaria di Kecamatan Silian Raya Kabupaten Minahasa Tenggara. Jenis penelitian ini adalah survey yang bersifat deskriptif. Populasi penelitian adalah masyarakat di Kecamatan Silian Raya Kabupaten Minahasa Tenggara dengan jumlah sampel 194 responden. Hasil penelitian menunjukkan bahwa masyarakat di Kecamatan Silian Raya sebagian besar memiliki tempat tinggal di sekitar rawa, sawah, sungai. Penelitian ini juga menunjukkan hanya sedikit masyarakat Kecamatan Silian Raya yang memiliki hewan peliharaan atau kolam ikan di sekitar tempat tinggal.
\end{abstract}

Kata kunci: malaria, lingkungan

Malaria merupakan penyakit menular yang disebabkan oleh parasit dari genus Plasmodium dan ditularkan melalui gigitan nyamuk Anopheles betina. Malaria masih menjadi masalah kesehatan di dunia termasuk di Indonesia. Penyakit ini dapat berdampak luas terhadap kualitas hidup dan ekonomi serta dapat mengakibatkan kematian. $^{1,2}$

Berdasarkan data World Health
Organization (WHO) 2013, pada tahun 2012 diperkirakan ada 207 juta kasus malaria di seluruh dunia dan 627.000 kasus malaria yang menyebabkan kematian. Penderita malaria tersebar di seluruh dunia terutama di daerah endemis seperti Afrika dan Asia. ${ }^{3}$

Indonesia juga merupakan salah satu negara yang masih berisiko terhadap kejadian malaria. Dari hasil Riset 
Kesehatan Dasar Republik Indonesia (Riskesdas RI) insiden malaria penduduk Indonesia pada tahun 2013 adalah 1,9 persen dengan insiden tertinggi di provinsi Papua. Di Sulawesi Utara insiden malaria pada tahun 2013 adalah 2,7 persen dan prevelensinya adalah 10,0 persen. ${ }^{4}$

Kabupaten Minahasa Tenggara merupakan salah satu kabupaten/kota dengan jumlah kasus malaria yang tinggi, yaitu terdapat 2001 kasus malaria positif pada tahun 2011 dan pada tahun 2012 terdapat 2005 kasus malaria positif. $^{5}$ Kecamatan Silian Raya Kabupaten Minahasa Tenggara terdiri dari 10 desa dengan jumlah penduduk 5731 jiwa (2014). Berdasarkan data puskesmas Silian pada bulan Januari sampai dengan bulan Oktober 2014, setiap bulannya didapatkan penduduk Kecamatan Silian Raya yang menderita malaria. Terdapat 637 orang yang datang ke puskesmas Silian pada bulan Januari sampai bulan Oktober 2014 dengan gejala malaria dan 159 orang yang dinyatakan positif malaria. $^{6}$

Beberapa faktor yang berperan terhadap kejadian malaria, salah satunya yaitu lingkungan yang memungkinkan nyamuk Anopheles berkembang biak dan berpotensi melakukan kontak dengan manusia dan menularkan parasit malaria. ${ }^{7}$ Beberapa penelitian sebelumnya, menyatakan adanya peranan yang dominan dari lingkungan terhadap kejadian malaria. Dari hasil penelitian Yudhastuti R (2008), keadaan lingkungan sekitar tempat tinggal seperti rawa, sawah, sungai dan kolam berperan terhadap kejadian malaria. Hal ini disebabkan karena tempat-tempat tersebut berpotensi sebagai tempat hidup nyamuk Anopheles. ${ }^{7}$ Hal ini sejalan dengan hasil penelitian Subki (2000) yang menyatakan adanya hubungan yang bermakna antara tempat perindukan nyamuk dengan kejadian malaria yaitu penduduk yang disekitar tempat tinggalnya ada tempat perindukan nyamuk (genangan air, kolong bekas galian timah, rawa, sungai dan kebun dengan jarak $<2 \mathrm{~km}$ dari tempat tinggal) mempunyai resiko 2,31 kali sampai 2,98 kali untuk terkena malaria dibandingkan orang yang di sekitar tempat tinggalnya tidak ada atau jauh $\geq 2 \mathrm{~km}$ ada tempat perindukan nyamuk. ${ }^{8}$ Dari beberapa penelitian sebelumnya, salah satu aspek lingkungan lain yang juga berperan terhadap kejadian malaria adalah hewan peliharaan. Menurut Yudhastuti (2006), adanya ternak besar seperti sapi dan kerbau dapat mengurangi jumlah gigitan nyamuk pada manusia ${ }^{7}$ namun berdasarkan hasil penelitian Ernawati (2011), menunjukkan bahwa pemeliharaan ternak lebih beresiko 1,10 kali terhadap kejadian malaria. ${ }^{9}$

Berdasarkan hal tersebut, maka penulis tertarik untuk melakukan penelitian tentang bagaimana peranan lingkungan terhadap kejadian malaria di Kecamatan Silian Raya Kabupaten Minahasa Tenggara.

\section{METODE PENELITIAN}

Jenis penelitian adalah survey yang bersifat deskriptif, untuk mengetahui peranan lingkungan masyarakat terhadap kejadian malaria di Kecamatan Silian Raya.

Sampel penelitian ini ialah masyarakat di Kecamatan Silian Raya Kabupaten Minahasa Tenggara yang bersedia berpartisipasi dalam penelitian ini. Jumlah sampel penelitian ditentukan berdasarkan rumus Slovin, ${ }^{10}$ sebagai berikut:

$$
\mathrm{n}=\frac{\mathrm{N}}{1+\mathrm{N}\left(\mathrm{d}^{2}\right)}
$$

$\mathrm{n}$ = Besarnya sampel

$\mathrm{N}=$ Besarnya populasi

$\mathrm{d}=$ Tingkat kepercayaan $(0,1)$

Sehingga jumlah nilai

$$
\mathrm{n}=\frac{5731}{1+5731\left(0,1^{2}\right)}=98,28=98
$$

Jumlah desa di Kecamatan Silian Raya adalah 10 desa, dengan demikian dapat dihitung jumlah sampel untuk masingmasing desa sebagai berikut:

$$
\mathrm{T}=\frac{\mathrm{t}}{\mathrm{N}} \times \mathrm{n}
$$


$\mathrm{T}=$ Jumlah sampel pada tiap desa

$\mathrm{t}=$ Jumlah Jiwa tiap desa

$\mathrm{N}=$ Besarnya populasi

$\mathrm{n}=$ Besarnya sampel

Penelitian dilaksanakan pada bulan Oktober 2014 - Januari 2015 di Kecamatan Silian Raya Kabupaten Minahasa Tenggara dan melibatkan 194 responden. Data primer diperoleh menggunakan kuesioner untuk menilai karakteristik responden dan dilakukan observasi secara langsung terhadap lingkungan sekitar tempat tinggal responden.

\section{HASIL PENELITIAN DAN BAHASAN}

Penelitian di Kecamatan Silian yang terdiri dari 10 desa ini dilakukan pada 194 responden baik laki-laki maupun perempuan. Umur responden yang diambil adalah 17 tahun keatas, karena merupakan usia produktif kerja dan bisa menjawab pertanyaan yang ada dalam kuesioner serta mengetahui keadaan lingkungan sekitar rumah.

Data pada Tabel 1 menunjukkan responden terbanyak terdapat pada kelompok umur 40-50 tahun sebanyak 52 responden $(26,8 \%)$ dan yang paling sedikit umur $<20$ tahun $(3,1 \%)$.

Tabel 1. Distribusi responden menurut kelompok umur

\begin{tabular}{ccc}
\hline Umur & Jumlah & \% \\
\hline$<20$ & 6 & 3,1 \\
$20-30$ & 40 & 20,6 \\
$30-40$ & 43 & 22,2 \\
$40-50$ & 52 & 26,8 \\
$50-60$ & 40 & 20,6 \\
$>60$ & 13 & 6,7 \\
\hline Jumlah & 194 & 100,0 \\
\hline
\end{tabular}

Data pada Tabel 2 menunjukkan responden terbanyak ialah perempuan yaitu 60,3\%. Hal ini dikarenakan pengambilan data dilakukan pada saat jam kerja yaitu pada pagi sampai siang hari, sehingga kebanyakan yang berada di rumah adalah perempuan sedangkan laki-laki banyak yang pergi bekerja di kantor ataupun kesawah/kebun.

Tabel 2. Distribusi responden menurut jenis kelamin

\begin{tabular}{ccc}
\hline Jenis Kelamin & Jumlah & \% \\
\hline Laki-laki & 77 & 39,7 \\
Perempuan & 117 & 60,3 \\
\hline Total & 194 & 100,0 \\
\hline
\end{tabular}

Data Tabel 3 menunjukkan pekerjaan responden terbanyak ialah IRT 51,0\% dan yang paling sedikit wiraswasta $2,6 \%$.

Tabel 3. Distribusi responden menurut pekerjaan

\begin{tabular}{lcc}
\hline \multicolumn{1}{c}{ Pekerjaan } & Jumlah & \% \\
\hline PNS/TNI/POLRI & 11 & 5,7 \\
Pegawai swasta & 1 & 5 \\
Pedagang & 4 & 2,1 \\
Petani/berkebun & 74 & 38,1 \\
IRT & 99 & 51,0 \\
Wiraswasta & 5 & 2,6 \\
\hline Total & 194 & 100,0 \\
\hline
\end{tabular}

Data Tabel 4 menunjukkan tingkat pendidikan responden yang terbanyak adalah tamat SMP 50,5\% dan yang paling sedikit adalah tamat perguruan tinggi 6,2\%. Hal ini perlu diketahui meski tingkat pendidikan tidak berpengaruh secara langsung terhadap kejadian malaria, namun pendidikan seseorang dapat mempengaruhi tingkat pengetahuan orang tersebut sehingga seseorang dengan tingkat pendidikan yang tinggi mempunyai cukup pengetahuan terhadap masalah-masalah yang terjadi di lingkungan sekitar.

Tabel 4. Distribusi responden menurut tingkat pendidikan

\begin{tabular}{ccc}
\hline Pendidikan & Jumlah & $\mathbf{\%}$ \\
\hline Tamat SD & 33 & 17,0 \\
Tamat SMP & 98 & 50,5 \\
Tamat & 51 & 26,3 \\
$\begin{array}{c}\text { SMU/sederajat } \\
\text { Tamat }\end{array}$ & 12 & 6,2 \\
perguruan & & \\
tinggi & & \\
\hline Total & 194 & 100,0 \\
\hline
\end{tabular}


Data Tabel 5 menunjukkan lebih banyak responden memiliki rumah dekat dengan rawa, sawah, sungai yaitu 100 responden $(51,1 \%)$ dan dari 100 responden terdapat 71 responden $(71,0 \%)$ yang memiliki rumah dekat rawa, sawah, sungai dengan jarak <10 m. Dari hasil penelitian didapatkan bahwa lebih banyak masyarakat di Kecamatan Silian Raya tinggal di rumah disekitar rawa, sawah, sungai yang dapat menjadi tempat perindukan nyamuk atau tempat nyamuk berkembangbiak. Hal ini sejalan dengan penelitian yang dilakukan oleh Kholis Ernawati dkk, tentang hubungan faktor resiko individu dan lingkungan rumah dengan malaria di Punduh Pedada Kabupaten Pesarawan Provinsi Lampung Indonesia 2010. ${ }^{9}$

Tabel 5. Distribusi responden berdasarkan keberadaan rawa, sawah, sungai yang menjadi tempat perindukan nyamuk disekitar rumah

\begin{tabular}{ccc}
\hline $\begin{array}{c}\text { Keberadaan tempat } \\
\text { perindukan nyamuk } \\
\text { disekitar rumah }\end{array}$ & Jumlah & $\mathbf{\%}$ \\
\hline Ya & 100 & 51,1 \\
Tidak & 94 & 48,5 \\
\hline Total & 194 & 100,0 \\
\hline $\begin{array}{c}\text { Jarak rumah dengan } \\
\text { tempat perindukan } \\
\text { nyamuk }<\mathbf{1 0 ~ m}\end{array}$ & & \\
\hline Ya & 71 & 71,0 \\
Tidak & 29 & 29,0 \\
\hline Total & 100 & 100,0 \\
\hline
\end{tabular}

Berdasarkan hasil penelitian ini juga didapatkan sebagian besar masyarakat yang memiliki rumah disekitar rawa, sawah, sungai jaraknya kurang dari $10 \mathrm{~m}$. Jarak terbang nyamuk Anopheles betina hanya sekitar 300-500 m, ${ }^{20}$ maka keberadaan tempat perindukan nyamuk pada radius tersebut merupakan faktor resiko bagi penduduk di pemukiman tersebut untuk terkena malaria. ${ }^{8}$

Data Tabel 6 menunjukkan sebagian besar responden tidak mempunyai hewan peliharaan disekitar rumah yaitu 70,1\%. Hal ini tidak sejalan dengan penelitian yang dilakukan di Punduh Pedada Kabupaten
Pesarawan Provinsi Lampung Indonesia oleh Ernawati yang menyatakan bahwa pemeliharaan hewan atau ternak dapat meningkatkan resiko terhadap kejadian malaria. $^{9}$

Tabel 6. Distribusi responden berdasarkan keberadaan hewan peliharaan disekitar rumah

\begin{tabular}{ccc}
\hline $\begin{array}{c}\text { Hewan peliharaan } \\
\text { disekitar rumah }\end{array}$ & Jumlah & $\mathbf{\%}$ \\
\hline Ya & 58 & 29,9 \\
Tidak & 136 & 70,1 \\
\hline Total & 194 & 100,0 \\
\hline
\end{tabular}

Data Tabel 7 menunjukkan sebagian besar responden tidak memiliki kolam disekitar rumah yaitu 87,6\%. Sementara responden yang memiliki kolam disekitar rumah dan memiliki ikan dikolam sebanyak 79,2\%. Hal ini sejalan dengan penelitian yang dilakukan Santy dkk, di Sungai Ayak 3 Kecamatan Belitang Hilir Kabupaten Sekadau. $^{11}$

Tabel 7. Distribusi responden terhadap keberadaan kolam disekitar rumah

\begin{tabular}{ccc}
\hline $\begin{array}{c}\text { Kolam disekitar } \\
\text { rumah }\end{array}$ & Jumlah & $\mathbf{\%}$ \\
\hline Ya & 24 & 12,4 \\
Tidak & 170 & 87,6 \\
\hline Total & 194 & 100,0 \\
\hline Ikan di kolam & & \\
\hline Ya & 19 & 79,2 \\
Tidak & 5 & 20,8 \\
\hline Total & 24 & 100,0 \\
\hline
\end{tabular}

\section{SIMPULAN}

Berdasarkan hasil penelitian dan bahasan yang dilakukan maka dapat disimpulkan bahwa lebih banyak masyarakat di Kecamatan Silian Raya Kabupaten Minahasa Tenggara yang tinggal di rumah disekitar rawa, sawah, sungai yang dapat menjadi tempat perindukan nyamuk. Juga didapatkan sebagian besar masyarakat Kecamatan Silian Raya tidak mempunyai hewan peliharaan atau kolam ikan disekitar rumah. 


\section{DAFTAR PUSTAKA}

1. Sutanto I, Ismid IS, Sjarifuddin PK, Sungkar S, editors. Parasitologi kedokteran. Edisi ke-4. Jakarta: FKUI; 2008. p. 189-217

2. Yudhastuti R, Hargono R. pengendalian malaria di daerah endemis dengan pendampingan key person. Jurnal kesehatan lingkungan. 2006;3:77-86

3. WHO. World malaria report 2013. Geneva: WHO; 2001. Available at: http://www.who.int/malaria/publicati ons/world_malaria_report_2013/wmr 2013_no_profiles.pdf?ua $=1$

4. Badan penelitian dan pengembangan kesehatan RI. 2013. Riset kesehatan dasar (Riskesdas) 2013. Jakarta: Kementerian Kesehatan RI.

5. Kecamatan Silian Raya. Profil Kecamatan Silian Raya. 2014

6. Data umum puskesmas Kecamatan Silian Raya tahun 2014
7. Yudhastuti R. Gambaran faktor lingkungan daerah endemis malaria berbatasan. Kesehatan lingkungan. 2008;4:9-20

8. Palupi NW. Hubungan keberadaan tempat perindukan nyamuk dengan kejadian malaria di puskesmas Hanura Kabupaten Pesawaran tahun 2010 [tesis]. [FKM]: UI; 2010

9. Ernawati K, Soesilo B, Duarsa A, Adah R. Hubungan faktor risiko individu dan lingkungan rumah dengan malaria di Punduh pedada kabupaten Pesawaran. Kesahatan. 2011;15:51-7

10. Setiawan N. Penentuan ukuran sampel memakai rumus slovin dan tabel Krejcie-Morgan: Telaah konsep dan aplikasinya. Fakultas peternakan Universitas Padjajadran. 2007

11. Santy, Agus F, Diana N. Hubungan faktor individu dan lingkungan dengan kejadian malaria di Sungai Ayak 3 Kecamatan Belitang Hilir Kabupaten Sekadau.2014;2:1. 